Original Article

\title{
Plant age, crop stage and surrounding habitats: their impact on sucking pests and predators complex in cotton (Gossypium hirsutum L.) field plots in arid climate at district Layyah, Punjab, Pakistan
}

\author{
Idade da planta, estágio da cultura e habitats circundantes: seu impacto no complexo \\ de pragas sugadoras e predadores em parcelas de algodão (Gossypium hirsutum L.) em \\ clima árido no distrito de Layyah, Punjab, Paquistão
}

\author{
A. Nadeem ${ }^{1}$ (D) , H. M. Tahir ${ }^{1}$ (D) and A. A. Khan²* (D) \\ ${ }^{1}$ Government College University, Department of Zoology, Lahore, Pakistan \\ ${ }^{2}$ Bahauddin Zakariya University, College of Agriculture, Bahadur Sub Campus, Layyah, Pakistan
}

\begin{abstract}
Sucking pests are major threat to cotton field crop which cause unbearable losses to the crop yield. Aim of the current study was to record seasonal dynamics of major sucking insect pests including whitefly, jassid, thrips and their natural arthropod predators i.e. green lacewings and spiders in cotton field plots. The effects of surrounding field crops on pests' density and predatory efficiency of predators were also recorded. For sampling and survey of insects, the visual counting was found to be the most efficient method for recording the abundance of insects, trailed by net sweeping and tapping. Whitefly was the most dominant sucking pest found on the vegetative stage of cotton, followed by jassid and thrips. Fluctuated populations of predatory arthropods, spiders and green lacewings were also recorded during whole cropping season however, the densities of pests and predators varied with crop phenology. Spiders' population was encouraging at both vegetative and flowering stage and also the same trend of jassid and whitefly were observed at both stages of the crop. Surrounding habitats showed non-significant effect on population densities of insect pests and predators. For abiotic factors, the spiders showed strong positive correlation with humidity and temperature. However, green lacewing was only positively correlated with humidity. On the other hand, the populations of whitefly, jassid and thrips showed non-significant correlation with both temperature and humidity. Overall densities of sucking insect pests were found above economic threshold level. The plant age, crop stage and surrounding habitats effect on the population fluctuation of pests as well as the predators' abundance. The future studies are also warranted to investigate the altered habitats and multiple trap cropping to find out their impact on unattended insect predators and parasitoids in cotton crop.
\end{abstract}

Keywords: seasonal dynamics, sucking pests, predators, crop phenology, habitat.

\section{Resumo}

As pragas sugadoras são uma grande ameaça para a cultura do algodão, causando perdas insuportáveis no rendimento da cultura. $\mathrm{O}$ objetivo do estudo atual foi registrar a dinâmica sazonal das principais pragas de insetos sugadores, incluindo mosca-branca, jassid, tripes e seus artrópodes predadores naturais, ou seja, crisopídeos e aranhas verdes em parcelas de algodão. Os efeitos das plantações circundantes na densidade de pragas e na eficiência predatória de predadores também foram registrados. Para amostragem e pesquisa de insetos, a contagem visual foi considerada o método mais eficiente para registrar a abundância de insetos, seguido por varredura e batida de rede. A mosca-branca foi a praga sugadora mais dominante encontrada na fase vegetativa do algodoeiro, seguida pelo jassid e tripes. Populações flutuantes de artrópodes predadores, aranhas e crisálidas também foram registradas durante toda a safra, no entanto as densidades de pragas e predadores variaram com a fenologia da cultura. A população de aranhas foi encorajadora tanto na fase vegetativa como na floração e também a mesma tendência de jassid e mosca-branca foi observada em ambas as fases da cultura. Os habitats circundantes mostraram efeito não significativo nas densidades populacionais de insetos-praga e predadores. Para os fatores abióticos, as aranhas apresentaram forte correlação positiva com umidade e temperatura. No entanto, lacewing verde foi apenas positivamente correlacionado com a umidade. Por outro lado, as populações de mosca-branca, jassid e tripes apresentaram correlação não significativa com temperatura e umidade. As densidades gerais de pragas

*e-mail: drkupchani@bzu.edu.pk

Received: April 12, 2020 - Accepted: November 25, 2020

This is an Open Access article distributed under the terms of the Creative Commons Attribution License, which permits unrestricted use, distribution, and reproduction in any medium, provided the original work is properly cited. 
sugadoras de insetos foram encontradas acima do nível do limiar econômico. A idade da planta, o estágio da cultura e os habitats circundantes afetam a flutuação populacional de pragas, bem como a abundância de predadores. Os estudos futuros também são necessários para investigar os habitats alterados e cultivo com armadilhas múltiplas para descobrir seu impacto sobre predadores de insetos e parasitoides desacompanhados na cultura do algodão.

Palavras-chave: dinâmica sazonal, pragas sugadoras, predadores, fenologia das culturas, habitat

\section{Introduction}

Cotton, Gossypium hirsutum L. (Malvales: Malvaceae) crop is attacked by a fairly high number of arthropod pests at its different phenological stages that cause significant loss to the farmers (Uthamasamy, 1994; Sahito et al., 2017). Yunus and Yousuf (1979) reported 93 insect species from cotton fields of Pakistan while Khan and Rao (1960) reported 235 insect species from Indian part of the sub-continent. In Pakistan about eighteen species of insects are found most destructive pests of cotton (Abbas, 2001). Generally, cotton insect pests are divided into two categories i.e., sucking pests and chewing pests. The borers are considered as the main threat to the cotton crop but in the recent years due to the introduction of $B t$ cotton, this threat has been shifted to sucking insect pests, especially Jassid \{ Amrasca biguttula Ishida (Hemiptera: Cicadellidae) $\}$ and whitefly \{Bemisia tabaci (Hemiptera: Aleyrodidae)\} (Ellsworth et al., 2001; Dhawan et al., 2011). In Pakistan, under favorable conditions different insect pests of cotton may collectively cause 35-50 percent damage to the crop yield (Naqvi, 1976; CCRI, 2005; Masood et al., 2011), while according to an estimate, globally insect pests cause $20-40$ percent loss to agricultural crops (Raman, 2017).

Jassids are characterized as most critical of all sucking pests as they suck cell sap from the plant tissues and in return inject their poisonous saliva into the plant body during its feeding. Their early attacks not only effects leaves but also results in reduction in photosynthetic area of the plant (Sahito et al., 2017). They may all alone causes 23.67 percent reduction in the total yield of cotton in any given field, if goes unchecked (Razaq et al., 2005). As polyphagous pests of some economically important crops including both agricultural and non-agricultural plantation and by sucking the cell sap from all tender parts of the plant including leaves, flowers, fruits and even stem, they adversely affect the overall plant activity and growth (Kamble and Sathe, 2015). Thrips \{Thrips tabaci Lindeman (Thysanoptera: Thripidae)\} invade the crop in early stages and hence causes adverse effects on the overall yield of the crop. Thrips are the most consistent and widespread pests of cotton in the United States, causing up to a 50\% reduction of lint yield (Cook et al., 2011). In U.S.A during a cropping season of 2009, thrips infested at its maximum i.e., almost $95 \%$ of total U.S. cotton acreage. In a ten-year study on cotton yield losses held from 2007-2016, arthropod pests reduced the national yield by $2.60 \%$ in which thrips contributed an average $0.423 \%$ loss (Williams, 2017). Its nymph and adult damage the plant leaves which results into the twisting of leaves. Presence of different crops at the cotton field boundaries provide greater chances to thrips for their quick immigration in large numbers and also increases its chances of greater infestation to the young cotton plants (Greenberg et al., 2009; Cook et al., 2013; Stewart et al., 2013). Environmental factors are difficult to predict with certainty so, to avoid any quick stress on young plants, chemical or insecticidal usage is generally and widely accepted (Cook et al., 2011). A recent model is being devised which incorporate information about temperature, rainfall and geological locations to predict thrips infestation (Kennedy et al., 2017). Whitefly damage the cotton crop severely by sucking cell sap from the lower surface of leaves which reduces boll production by fifty percent (Ahmad et al., 2002) and it not only weaken the leaves but also results in weakening of the whole plant (Umaharan et al., 1998). During the feeding whitefly secretes honey dews which in turn helps the sooty mold to attack on crop leaves and reduces the photosynthetic portion of the leave. In addition to direct damage whitefly also vectors, Cotton leaf curl virus and Tobacco Streak Virus (Nelson et al., 1998).

Environmental factors like humidity, temperature and rainfall also affects the population densities of sucking insect pests. High temperature has negative effects on jassid; however, positive impacts on whitefly populations (Dhaka and Pareek, 2008). The aims of present study were to record the seasonal dynamics of insect pests and their natural predators; their population dynamics in relation to crop phenology and the impacts of field boundary habitats on the diversity and abundance of natural enemies of insects. The outcome of research will provide a road map to design any strategy for the management of insect pests of cotton in the area. At the same time knowledge about predatory fauna and impacts of surrounding habitats will also helpful for the betterment of the crop production. The population fluctuation of pests and their predators with reference to crop phenology is also a facility to decide any management practice at any desired stage of the crop.

\section{Materials and Methods}

The present study was carried out at District Layyah, province Punjab in Pakistan during the cotton growing season (May-October, 2018) to observe the seasonal occurrence of sucking insect pests and their natural predators in cotton field plots. Three different locations viz: Chak 140 (Longitude 71.05438, Latitude 30.96173), Karor (Longitude 70.98401, Latitude 31.17979) and Hafizabad (Longitude 70.92055, Latitude 30.81586) were designated as hotspots for data collection and from each site five field plots of $800 \mathrm{~m}^{2}$ were selected. The surrounding habitats of selected experimental plots at all the three locations were consisting of three groups (1) Monoculture, (2) Sesame and (3) intercropping of Sugarcane and Sesame. These surrounding field plots (Habitats) were also the cultured by using standard agronomic practices. Therefore, no unwanted vegetation was available in these surroundings. Bt cotton (FH-142) was cultivated and sowing was done from 
May 14 to May 17, 2018 at all experimental plots at different selected locations belonging to same geographical zone.

For the observation and recording of pests and predators during the whole cropping period, following three methods i.e. tapping, net sweeping and visual observation were used for sample collection and recording of data. Tapping was used for the picking-up of soft bodied pests as it was difficult to collect those through hand picking. Net sweeping was done for capturing flying arthropods predators like green lacewings and pests like whitefly etc. (Kharboutli and Allen, 2000). The visual counting was adopted for the precise estimation of different pest parameters like abundance and their total numbers present in the cotton field plots.

Initially the cotton seed germination was recorded after $3^{\text {rd }}$ and $4^{\text {th }}$ week from the date of sowing at different locations. No special plant protection measures were applied at any selected site throughout the season. However, only standard and recommended agronomic practices (like irrigation, fertilizers, weeding etc.) were practiced when and where required.

Twenty-five plants were selected randomly from each selected field of each site and population of thrips, jassid, whitefly, spider and green lacewing was counted per plant i.e. three leaves per plant, each from top, middle and bottom of the selected plant were observed (Kedar et al., 2016). The abundance of each pest and predator was recorded during crop phenological stages (vegetative, flowering and boll formation). Similarly, data for insect pests and predators' density was also observed with respect to the surrounding field boundary habitats.

During the cropping season, each stage of the crop was prolonged for several days even for weeks. Therefore, we have observed the data for eight different dates depending on the phenological status of the crop. During each of the sampling dates, the data regarding abiotic factors (i.e., humidity and temperature) was recorded form the observatory of the Bahauddin Zakariya University, Bahadur Campus Layyah (Punjab) Pakistan. Prior to statistical analysis, the normality of collected data was confirmed through Shapiro-Wilk test. Analysis of variance (one-way) followed by Tukey's test was used to compare the mean densities of pests and predators among the experimental field plots for different treatments. The statistical package SPSS $^{\circledR}$ (Version 16) was used for analyses of whole data. The results are presented as mean \pm SEM and percentage as required.

\section{Results}

The seasonal fluctuation was recorded in the densities of insect pests and predators throughout the cropping season i.e. June-September 2018. The relative abundance of whitefly (74\%) was highest followed by jassid (12\%) and thrips (7\%). Collectively pest population contributed $93 \%$ to the total count. However, the relative abundance of spiders (Araneae) and green lacewings \{Chrysoperla carnea Stephens (Neuroptera: Chrysopidae)\} was $4 \%$ and $3 \%$ respectively (Figure 1 ).

Whitefly dominated the entire sucking insect pest's community right from the day one till the last observation date. There was significant variation in the density of whitefly among different trapping dates $\left(\mathrm{F}_{8,992}=51.84\right.$, $\mathrm{P}<0.05$ ). Jassid and thrips population also varied significantly among trapping dates $\left(\mathrm{F}_{8,992}=40.21, \mathrm{P}<0.05\right.$ for Jassid and $\mathrm{F}_{8,992}=24.58, \mathrm{P}<0.05$ for Thrips). We also recorded significant difference in the densities of spider $\left(\mathrm{F}_{8,992}=32.21, \mathrm{P}<0.05\right)$ and green lacewing $\left(\mathrm{F}_{8,992}=30.76\right.$, $\mathrm{P}<0.05$ ) during different sampling periods (Figure 2). A significant variation in population of pests and predators was found during all three crop stages $(\mathrm{F}=51.09, \mathrm{P}<0.001$ for whitefly, $\mathrm{F}=52.15, \mathrm{P}<0.001$ for Jassids, $\mathrm{F}=38.58$, $\mathrm{P}<0.001$ for thrips, $\mathrm{F}=40.93, \mathrm{P}<0.001$ for Green lacewing and $\mathrm{F}=76.98, \mathrm{P}<0.001$ for spiders (Figure 3 ). Results of Tukey's test showing comparison of mean density of insect pests and predators at different trapping dates are depicted in Table 1.

Figure 4 is showing the impacts of different field boundaries on mean population of insect pest and predators. Although the population density of jassid and whitefly was affected with surroundings field boundaries but the impact was statistically non-significant $(P<0.05)$. Similar trend was observed for spiders and lacewings (Figure 4). The spider and green lacewing populations showed strong positive correlation with humidity. Spiders also showed significant correlation with temperature. The populations of jassid, whitefly and thrips show non-significant correlation both with temperature and humidity (Table 2).

\section{Discussion}

Different methods such as visual searching, net sweeping and tapping methods are considered important for population estimation of insect pests and their predators in cotton field plots. Current studies have aimed to find out the seasonal dynamics of sucking insect pests from different habitats during the cropping season and crop stages. Our findings of insect pest densities (whitefly

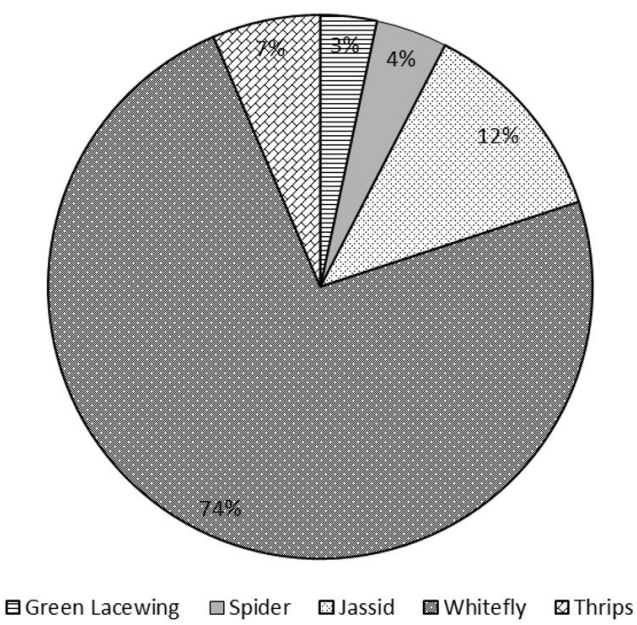

Figure 1. Percent numbers of sucking insect pests (jassid, thrips, whitefly) and predators (green lacewing, spider) in cotton field plots at three locations (five replications) during 2018 at Layyah, Punjab, Pakistan. 


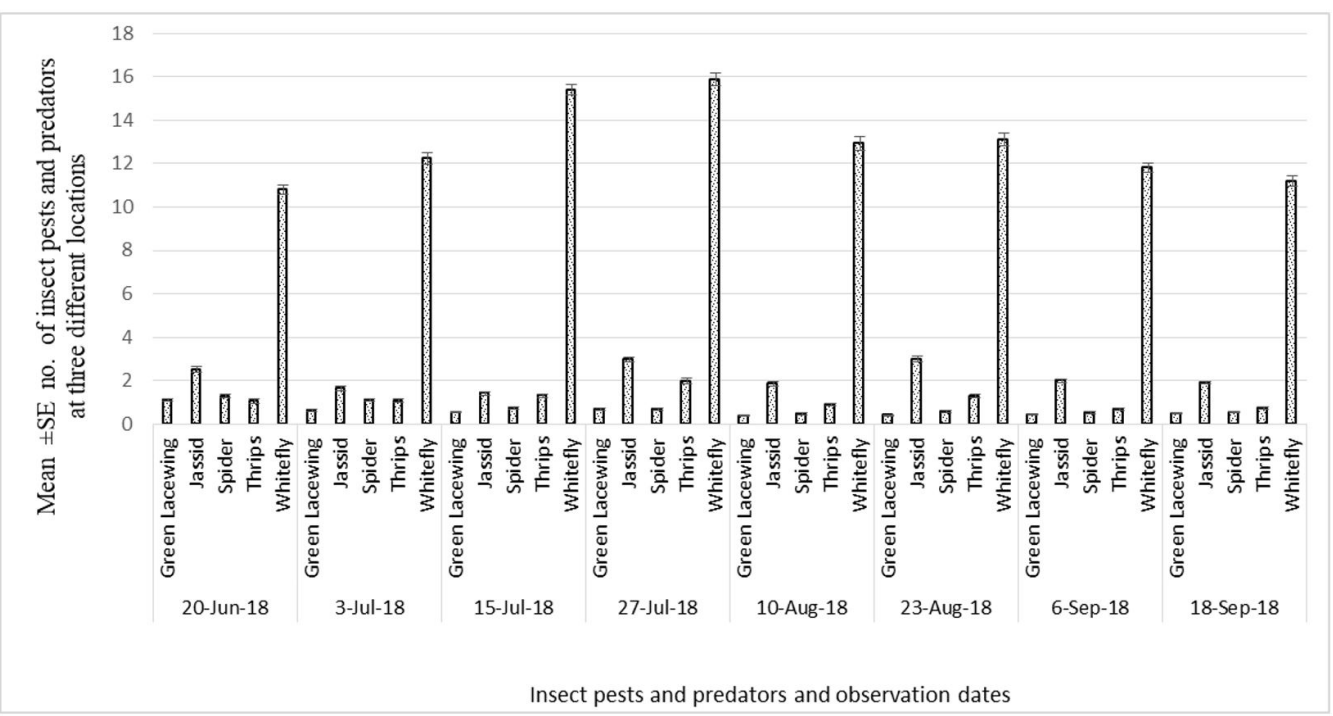

Figure 2. Means ( \pm SE) number of sucking insect pests (jassid, thrips, whitefly) and predators (green lacewing, spider) in cotton field plots at three locations (five replications) during cropping season of cotton from June 20 to September 18, 2018 at Layyah, Punjab, Pakistan.

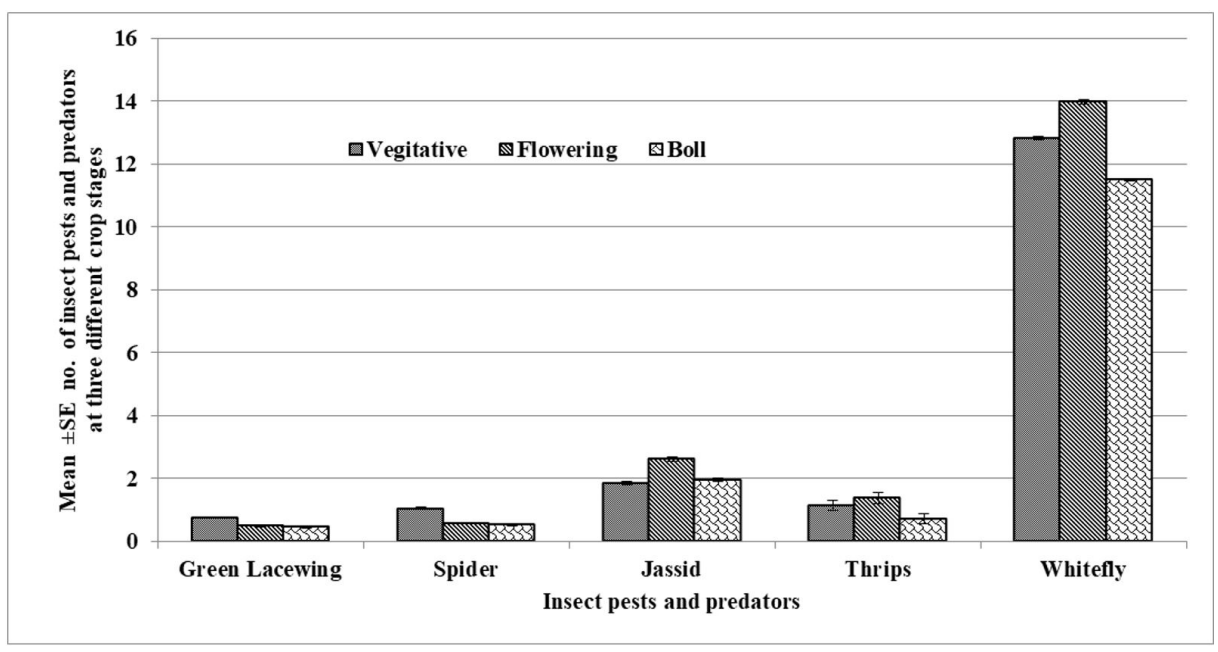

Figure 3. Means $( \pm S E)$ number of sucking insect pests (jassid, thrips, whitefly) and predators (green lacewing, spider) in cotton field plots at three locations (five replications) at different crop developmental stages (crop phenology) of cotton from June 20 to September 18, 2018 at Layyah, Punjab, Pakistan.

Table 1. The comparison of mean density of insect pests and predators at different trapping dates.

\begin{tabular}{ccccccc}
\hline Trapping Dates & Crop stage & Whitefly & Jassids $^{*}$ & Thrips $^{*}$ & $\begin{array}{c}\text { Green } \\
\text { Lacewing** }\end{array}$ & Spiders $^{* *}$ \\
\hline 20-Jun-18 & Vegetative & $10.792 \pm 0.2273^{\mathrm{d}}$ & $2.5173 \pm 0.1087^{\mathrm{b}}$ & $1.0533 \pm 0.1053^{\mathrm{bc}}$ & $1.1067 \pm 0.0492^{\mathrm{a}}$ & $1.2853 \pm 0.0710^{\mathrm{a}}$ \\
3-Jul-18 & Vegetative & $12.235 \pm 0.2605^{\mathrm{bc}}$ & $1.6453 \pm 0.0886^{\mathrm{cd}}$ & $1.0853 \pm 0.0781^{\mathrm{bc}}$ & $0.6293 \pm 0.0459^{\mathrm{bc}}$ & $1.1200 \pm 0.0544^{\mathrm{a}}$ \\
15-July-18 & Flowering & $15.400 \pm 0.2299^{\mathrm{a}}$ & $1.4213 \pm 0.0836^{\mathrm{d}}$ & $1.3120 \pm 0.0781^{\mathrm{b}}$ & $0.5547 \pm 0.0423^{\mathrm{bcd}}$ & $0.7280 \pm 0.0514^{\mathrm{b}}$ \\
27-July-18 & Flowering & $15.891 \pm 0.2890^{\mathrm{a}}$ & $2.9947 \pm 0.1092^{\mathrm{a}}$ & $1.9707 \pm 0.1233^{\mathrm{a}}$ & $0.6720 \pm 0.0526^{\mathrm{b}}$ & $0.6827 \pm 0.0509^{\mathrm{bc}}$ \\
10-Aug-18 & Flowering & $12.928 \pm 0.3001^{\mathrm{b}}$ & $1.8613 \pm 0.0936^{\mathrm{c}}$ & $0.8933 \pm 0.0628^{\mathrm{cd}}$ & $0.4027 \pm 0.0342^{\mathrm{d}}$ & $0.4667 \pm 0.0413^{\mathrm{c}}$ \\
23-Aug-18 & Boll stage & $13.099 \pm 0.2984^{\mathrm{b}}$ & $3.0080 \pm 0.1243^{\mathrm{a}}$ & $1.2933 \pm 0.0888^{\mathrm{b}}$ & $0.4053 \pm 0.0336^{\mathrm{d}}$ & $0.5867 \pm 0.0523^{\mathrm{bc}}$ \\
6-Sep-18 & Boll stage & $11.816 \pm 0.2297^{\mathrm{cd}}$ & $2.0027 \pm 0.0866^{\mathrm{c}}$ & $0.6773 \pm 0.0505^{\mathrm{d}}$ & $0.4480 \pm 0.0353^{\mathrm{d}}$ & $0.5387 \pm 0.0477^{\mathrm{bc}}$ \\
18-Sep-18 & Boll stage & $11.187 \pm 0.2321^{\mathrm{cd}}$ & $1.9040 \pm 0.0733^{\mathrm{c}}$ & $0.7493 \pm 0.0497^{\mathrm{cd}}$ & $0.4827 \pm 0.0372^{\mathrm{cd}}$ & $0.5520 \pm 0.0471^{\mathrm{bc}}$ \\
\hline
\end{tabular}

Data recorded for: * Per Leaf and ${ }^{* *}$ Per Plant 


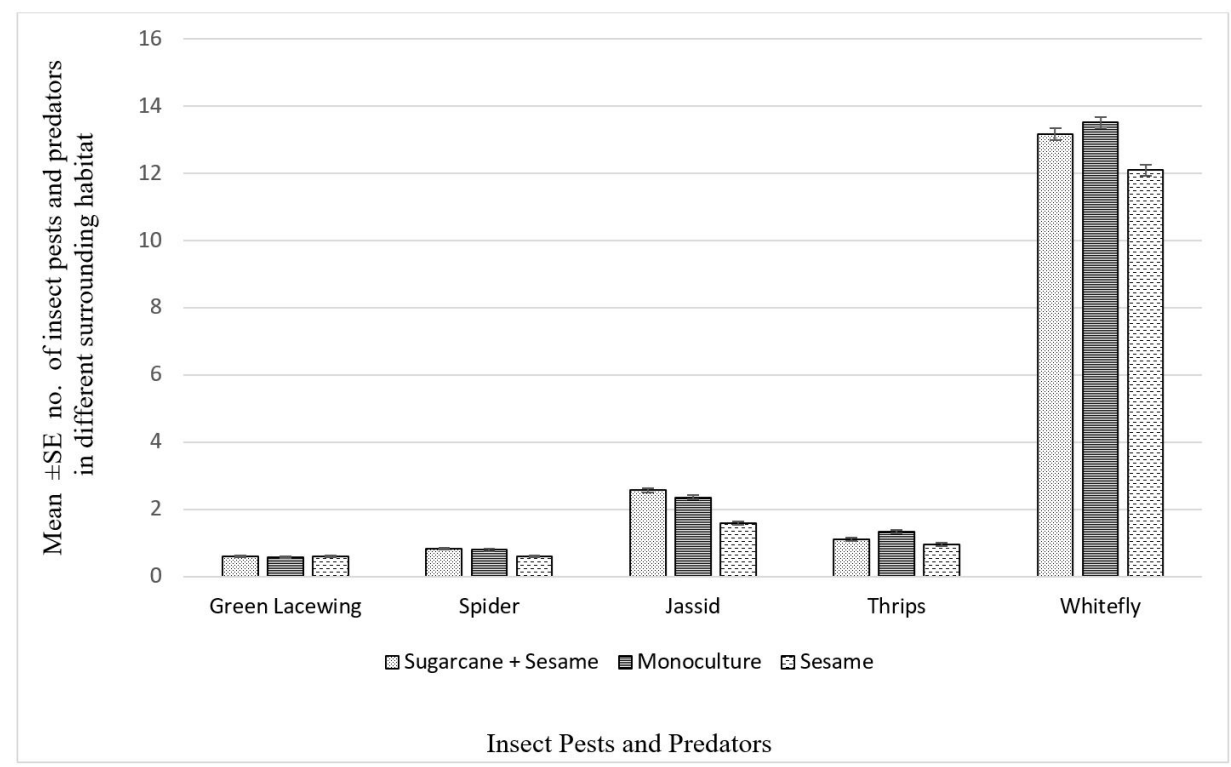

Figure 4. Means $( \pm S E)$ number of sucking insect pests (jassid, thrips, whitefly) and predators (green lacewing, spider) in cotton field plots at three locations (five replications) with different surrounding habitats (sugarcane + sesame, monoculture, sesame) during cropping season of cotton from June 20 to September 18, 2018 at Layyah, Punjab, Pakistan.

Table 2. Association of temperature and humidity on the population densities of cotton insect pests (jassid, whitefly and thrips), and their natural predators (spiders and green lacewings) during the crop season in the year 2018.

\begin{tabular}{|c|c|c|c|}
\hline Sr. No. & Pest/Predator & Temperature & Humidity \\
\hline \multirow[t]{2}{*}{1} & Spiders & $\mathrm{r}=0.467^{*}$ & $\mathrm{r}=0.652^{* *}$ \\
\hline & & $\mathrm{p}=0.021$ & $\mathrm{p}=0.001$ \\
\hline \multirow[t]{2}{*}{2} & Green lacewing & $r=0.360$ & $\mathrm{r}=0.733^{* *}$ \\
\hline & & $\mathrm{p}=0.084$ & $\mathrm{p}=0.000$ \\
\hline \multirow[t]{2}{*}{3} & Jassid & $\mathrm{r}=-0.020$ & $\mathrm{r}=-0.007$ \\
\hline & & $\mathrm{p}=0.926$ & $\mathrm{p}=0.973$ \\
\hline \multirow[t]{2}{*}{4} & Whitefly & $r=0.340$ & $\mathrm{r}=-0.196$ \\
\hline & & $\mathrm{p}=0.104$ & $\mathrm{p}=0.359$ \\
\hline \multirow[t]{2}{*}{5} & Thrips & $r=0.366$ & $\mathrm{r}=0.174$ \\
\hline & & $\mathrm{p}=0.079$ & $\mathrm{p}=0.417$ \\
\hline
\end{tabular}

${ }^{*}$ Correlation is significant at the 0.05 level. ${ }^{* *}$ Correlation is significant at the 0.01 level.

$74 \%$, jassid $12 \%$, thrips $7 \%$ ) and associated predators (spider 4\% and green lacewing 3\%) are in accordance with Amin et al. (2008) who found 4.50, 2.15 and 4.50 whitefly, jassid, thrips per leaf respectively in cotton crop from the fields with almost similar geographic conditions located at Sadarpur, Dinajpur. The comparative density (93: 7) \% of pests and associated predators was recorded throughout the cropping season. This is not surprising as number of predators are always less in comparison with prey. Whitefly showed maximum value $74 \%$ and unaffected against all the insecticides applied to the crop.

Through periodical way the population of all sucking insect pest complex and predators was varied throughout the cropping season in cotton field plots from June-
September 2018. However, this fluctuation was different for each insect and their associated predators. Elevated trend of whitefly on cotton was recorded (10.79 \pm 0.22 to $15.89 \pm 0.28$ ) from June to end July 2018. These observations are in accordance with Dhaka and Pareek (2008) who reported the incidence of whitefly at its peak at later stages of cotton crop. Thrips also showed almost same pattern of gradually increased numbers $(0.67 \pm 0.50$ to $1.97 \pm 0.12)$ from June to end of July 2018 as studied by Cook et al. (2011) and Cook et al. (2013), however Albeldano et al. (2008) has some different findings that thrips causes more damages during early season and early stages of cotton, but their findings are about ratio of damages not for the population dynamics. Same trend was also recoded for jassid population ( $1.42 \pm 0.08$ to $3.00 \pm 0.12$ ) round the 
cropping season which in confirmatory with finding of Dhaka and Pareek (2008), who reported sucking pest's peak population during 32th and 33th weak of crop growth. Shahid et al. (2012) also recorded maximum populations of whitefly (22.33 \pm 2.85$)$, jassid (3.33/leaf) and thrips (17.67 \pm 1.45 ) during July to August. So, the present study also confirms that with advanced vegetative growth of the plants with more leaf area, encourages sucking insect pest's populations.

Border crops and surroundings habitats also have significant effects on populations of sucking insect pest populations of cotton field plots. In current investigations it was observed that whitefly shifted to sesame which decreased the population on cotton crop as compared to monoculture. At the same time the significant reduction of jassid was also observed in cotton crops which was surrounded with sesame. However, for thrips this difference was neglectable either observed in monoculture or with different surrounding habitats. This trend of insect shifting is also in accordance with the studies of Devi (2018), who observed significant reduction in thrips and whitefly population and more predators number in cotton+sesame as compared to sole cotton. So, this is encouraging for predator conservation and pests shifting if we include border crops as surrounding habitats in cotton growing area.

The predators such as green lacewings and spiders showed their maximum numbers initially which kept on fluctuating and showed their minimum population during mid-August 2018. The declining numbers were recorded as ( $1.10 \pm 0.04$ to $0.40 \pm 0.03)$ and ( $1.28 \pm 0.07$ to $0.46 \pm 0.04$ ) for green lacewings and spiders respectively. Charjan et al. (2017) also found the same observation regarding predator's population of spiders and green lacewing having significant and positive correlation with maximum temperature.

\section{Conclusion}

For recording of data of pests and predator's visual observation was found best among all other available methodologies. Whitefly remained as dominant pests throughout the cropping season. The surrounding field crops though effect the active densities and population dynamics of some pests and predators but their overall impact remains statistically non-significant. it is concluded that the population of both pests and predators follow the crop phenology too.

\section{Acknowledgements}

We are thankful to the local farmers for the provision of crop fields area for the current research. We are also grateful to Department of Entomology, College of Agriculture, Bahauddin Zakariya University, Bahadur Campus Layyah-Pakistan for providing entomological equipment and related facilities. No funding was available for the current studies.

\section{References}

ABBAS, M.A., 2001. General agriculture. 2nd ed. Pakistan: Publ. Emporium, $352 \mathrm{p}$.

AHMAD, M., ARIF, M.I., AHMAD, Z. and DENHOLM, I., 2002. Cotton whitefly Bemisia tabaci resistance to organophosphate and pyrethroid insecticides in Pakistan. Pest Management Science, vol. 58, no. 2, pp. 203-208. http://dx.doi.org/10.1002/ps.440. PMid:11852647.

ALBELDANO, W.A., SLOSSER, J.E. and PARAJULEE, M.N., 2008. Identification of thrips species on cotton on the Texas Rolling Plains. Southwestern Entomologist, vol. 33, no. 1, pp. 43-51. http://dx.doi.org/10.3958/0147-1724-33.1.43.

AMIN, M.R., AHAD, M.A., HOSSAIN, M.H., HOSSAIN, S.M.A. and TITHI, D.A., 2008. Characteristics of some cotton varieties in relation to seasonal abundance of pests, predators and their impact on yield and quality. Journal of Agroforestry and Environment, vol. 2, no. 2, pp. 67-70.

CENTRAL COTTON RESEARCH INSTITUTE - CCRI, 2005. Annual Report. Multan, Punjab, Pakistan: CCRI, 23 p.

CHARJAN, Y.D., WANKHADE, S.R. and KARALE, G.V., 2017. Seasonal incidence of major sucking pests and predators on cotton (Gossypium spp.). International Journal of Current Research and Modern Education, vol. 2, no. 1, pp. 171-176.

COOK, D., HERBERT, A., AKIN, D.S. and REED, J., 2011. Biology, crop injury, and management of thrips (Thysanoptera: Thripidae) infesting cotton seedlings in the United States. Journal of Integrated Pest Management, vol. 2, no. 2, pp. B1-B9. http:// dx.doi.org/10.1603/IPM10024.

COOK, D.R., LEONARD, B.R., BURRIS, E. and GORE, J., 2013. Impact of thrips infesting cotton seedlings on cotton yield distribution and maturity. Journal of Cotton Science, vol. 17, pp. 23-33.

DEVI, S., 2018. Effect of intercropping on sucking insect pests and natural enemies of cotton. International Journal of Current Microbiology and Applied Sciences, vol. 7, no. 4, pp. 1101-1109. http://dx.doi.org/10.20546/ijcmas.2018.704.120.

DHAKA, S.R. and PAREEK, B.L., 2008. Weather factors influencing population dynamics of major insect pests of cotton under semi-arid agro-ecosystem. Indian Journal of Entomology, vol. 70, pp. 157-163.

DHAWAN, A.K., SHERA, P.S. and KUMAR, V. (2011) Bt cotton in India: adoption and impact analysis. In: A.K. DHAWAN, B. SINGH, R. ARORA and M.B. BHULLAR, eds. In: Recent Trends in Integrated Pest Management, Invited papers of the 3rd Congress on Insect Science, Pest Management for Food Security and Environmental Health, 18-20 April 2011, Ludhiana. Ludhiana, India: INSAI, PAU, pp 12-33.

ELLSWORTH, P.C., MATHEO, R.L. and MARTINEZ, C.J.L., 2001. IPM for Bemisia tabaci; a case study from North America. Crop Protection, vol. 20, no. 9, pp. 853-869. http://dx.doi.org/10.1016/ S0261-2194(01)00116-8.

GREENBERG, S.M., LIU, T.-X. and ADAMCZYK, J.J., 2009. Thrips (Thysanoptera: Thripidae) on cotton in the lower Rio Grande Valley of Texas: species composition, seasonal abundance, damage, and control. Southwestern Entomologist, vol. 34, no. 4, pp. 417-430. http://dx.doi.org/10.3958/059.034.0406.

KAMBLE, C.S. and SATHE, T.V., 2015. Incidence and host plants for Amrasca biguttula (Ishida) from Kolhapur Region, India. International Journal of Development Research, vol. 5, no. 3, pp. 3658-3661.

KEDAR, S.C., SAINI, R.K. and KUMARANAG, K.M., 2016. Seasonal incidence of Bemisia tabaci (Gennadius) on Bt cotton in relation to weather parameters. Journal of Entomological Research, 
vol. 40, no. 3, pp. 249-254. http://dx.doi.org/10.5958/09744576.2016.00045.1.

KHARBOUTLI, M.S. and ALLEN, C.T. (2000) Comparison of sampling techniques for tarnished plant bug and predaceous arthropods. In: 2000 Proceedings Beltwide Cotton Conferences. Volume 2, 4-8 January 2000, San Antonio, USA. Memphis: National Cotton Council, pp. 1131-1133.

KENNEDY, G.T., CHAPPELL, R.W. and DEPOLT, K., 2017. [viewed 12 April 2020] Thrips infestation predictor for cotton [online] NC State University. Available from: http://products.climate. ncsu.edu/ag/Cottontip

KHAN, Q. and RAO, V.P., 1960. Cotton in India - A monograph. Bombay: Indian Central Cotton Committee Publication, pp. 217-301.

MASOOD, A., ARIF, M.J., HAMED, M. and TALPUR, M.A., 2011. Field performance of Trichogramma chilonis against cotton bollworms infestation in different cotton varieties as a sustainable IPM approach. Pakistan Journal of Agriculture, Agricultural Engineering E Veterinary Sciences, vol. 27, no. 2, pp. 176-184.

NAQVI, K.M., 1976. Crop protection to boost up cotton production. In: Proceedings of the Cotton Production Seminar ESSO Fertilizer Co. Ltd. 29-30 April, Sukkur, Pakistan. pp. 119-125.

NELSON, M.R., NADEEM, A., AHMAD, W. and ORUM, T.V., 1998. Global assessment of cotton viral diseases. In: Proceedings Beltwide Cotton Conference, 5-9 January 1998, San Diego, CA. Memphis, TN: National Cotton Council, pp. 161-162.

RAMAN, R., 2017. The impact of Genetically Modified (GM) crops in modern agriculture: A review. GM Crops and Food: Biotechnology in Agriculture and the Food Chain, vol. 8, no. 4, pp. 195-208. http:// dx.doi.org/10.1080/21645698.2017.1413522. PMid:29235937.

RAZAQ, M., SUHAIL, A., ASLAM, M., ARIF, M.J., SALEEM, M.A. and KHAN, M.H.A., 2005. Evaluation of neonicotinoids and conventional insecticides against cotton jassid, Amrasca devastans (Dist.) and cotton whitefly, Bemisia tabaci (Genn.). on Cotton. Pakistan Entomologist, vol. 27, no. 1, pp. 75-78.

SAHITO, H.A., SHAH, Z.H., KOUSAR, T., MANGRIO, W.M., MALLAH, N.A., JATOI, F.A. and KUBAR, W.A., 2017. Comparative efficacy of novel pesticides against Jassid, Amrasca biguttula biguttula (Ishida) on cotton crop under field conditions at Khairpur, Sind, Pakistan. Singapore Journal of Scientific Research, vol. 7, no. 1, pp. 1-8. http://dx.doi.org/10.3923/sjsres.2017.1.8.

SHAHID, M.R., FAROOQ, J., MAHMOOD, A., ILAHI, F., RIA, M., SHAKEEL, A., PETRESCU-MAG, I.V. and FAROOQ A., 2012. Seasonal occurrence of sucking insect pest in cotton ecosystem of Punjab, Pakistan. Advances in Agriculture \&' Botanics, vol. 4, pp. 26-30.

STEWART, S.D., AKIN, D.S., REED, J., BACHELER, J., CATCHOT, A., COOK, D., GORE, J., GREENE, J., HERBERT, A., JACKSON, R.E. and KERNS, D.L., 2013. Survey of thrips species infesting cotton across the Southern US Cotton belt. Journal of Cotton Science, vol. 17, no. 4, pp. 263-269.

UMAHARAN, P., PADIDAM, M., PHELPS, R.H., BEACHY, R.N. and FAUQUET, C.M., 1998. Distribution and diversity of geminiviruses in Trinidad and Tobago. Phytopathology, vol. 88, no. 12, pp. 1262-1268. http://dx.doi.org/10.1094/PHYTO.1998.88.12.1262. PMid:18944827.

UTHAMASAMY, S., 1994. Intra and inter plant behavioural dynamics of the cotton bollworm complex. In: T.N. ANANTHAKRISHNAN, ed. Functional dynamics of Phytophagous insects. New Delhi: Oxford and IBH Publishers, pp. 115-131.

WILLIAMS, M.R., 2017. Cotton insect losses - 2016. In: Proceedings Beltwide Cotton Conference, 4-6 January 2017, Memphis, TN: National Cotton Council, pp 710-754

YUNUS, M. and YOUSUF, M., 1979. Insect and mite pests of cotton in Pakistan. Pakistan Journal of Agricultural Sciences, vol. 16, no. 1-2, pp. 67-71. 